\title{
Gas exchanges and production of West Indian cherry cultivated under saline water irrigation and nitrogen fertilization
}

\section{Trocas gasosas e produção da aceroleira irrigada com águas salinas e adubação com nitrogênio}

\author{
Geovani Soares de Lima ${ }^{1 *}$; Francisco Wesley Alves Pinheiro²; Adaan Sudário \\ Dias $^{2}$; Hans Raj Gheyi ${ }^{3}$; Reginaldo Gomes Nobre ${ }^{4}$; Lauriane Almeida dos Anjos \\ Soares ${ }^{5}$; André Alisson Rodrigues da Silva ${ }^{2}$; Evandro Manoel da Silva ${ }^{2}$
}

\begin{abstract}
West Indian cherry is of great socioeconomic importance to Brazil because of its potential to keep local workers in rural areas and generate income. It is mainly cultivated in the Northeast region, where high salt concentrations are common in water. This study was conducted to evaluate gas exchanges and production of West Indian cherry cultivar (cv.) 'BRS 366 Jaburu', as a function of irrigation with water of different salinity levels, and nitrogen fertilization, at the post-grafting stage. The experiment was carried out in pots adapted into drainage lysimeters, under greenhouse conditions in Campina Grande, PB, Brazil. The experimental design was randomized blocks with three replicates, using a $2 \times$ 4 factorial arrangement in which the treatments corresponded to two levels of irrigation water electrical conductivity (ECw: 0.8 and $4.5 \mathrm{dS} \mathrm{m}^{-1}$ ) and four nitrogen doses (ND: 70, 85, 100, and 115\% of the recommended dose). The $100 \%$ dose corresponded to $200 \mathrm{~g}$ of nitrogen per plant per year. Irrigation water electrical conductivity of $4.5 \mathrm{dS} \mathrm{m}^{-1}$ led to alterations in the gas exchanges and production components of West Indian cherry cv. 'BRS 366 Jaburu'. An increase in intercellular $\mathrm{CO}_{2}$ concentration resulted in the occurrence of non-stomatal effects on the assimilation rate of $\mathrm{CO}_{2}$ under water salinity conditions of $4.5 \mathrm{dS} \mathrm{m}^{-1}$. The mean weight of West Indian cherry fruits was reduced when nitrogen doses were above $85 \%$ of the recommended level. Nitrogen doses above $70 \%$ of the recommended dose (140 g per plant) intensified the negative effects of salt stress on the total number and weight of West Indian cherry fruits.
\end{abstract}

Key words: Malpighia emarginata. Physiology. Salt stress. Mineral nutrition.

\section{Resumo}

A aceroleira possui grande importância socioeconômica no Brasil, devido o seu potencial como fixadorde-mão de obra e geração de renda, sendo cultivada principalmente na região nordeste do Brasil, onde

\footnotetext{
' Prof. Visitante, Unidade Acadêmica de Ciências Agrárias, Universidade Federal de Campina Grande, UFCG, Pombal, PB, Brasil. E-mail: geovani.soares@pq.cnpq.br

2 Discentes, Curso de Doutorado, Programa de Pós-Graduação em Engenharia Agrícola, UFCG, Centro de Tecnologia e Recursos Naturais, Campina Grande, PB, Brasil. E-mail: wesley.ce@hotmail.com; adaansudariodias@gmail.com; andrealisson_cgpb@ hotmail.com; evandroagroman@hotmail.com

3 Prof. Visitante, Núcleo de Engenharia de Água e Solo, Universidade Federal do Recôncavo da Bahia, UFRB, Cruz das Almas, BA, Brasil. E-mail: hans@pq.cnpq.br

4 Prof., Departamento de Ciências e Tecnologia, Universidade Federal Rural do Semi-Árido, UFERSA, Caraúbas, RN, Brasil. E-mail: rgomesnobre@yahoo.com.br

5 Profa, Unidade Acadêmica de Ciências Agrárias, UFCG, Pombal, PB, Brasil. E-mail: lauriane.soares@pq.cnpq.br

" Author for correspondence
} 
são frequentes recursos hidricos com elevada concentrações de sais. Neste contexto, conduziu-se esta pesquisa com o objetivo de avaliar as trocas gasosas e a produção da aceroleira cv. BRS 366 Jaburu, em função da irrigação com águas de diferentes níveis de salinidades e adubação com nitrogênio, na fase de pós-enxertia. A pesquisa foi realizada em vasos adaptados como lisímetros de drenagem em condições de casa-de-vegetação, em Campina Grande, PB. O delineamento experimental foi o de blocos casualizados, com três repetições, usando o arranjo fatorial $2 \times 4$, cujos tratamentos consistiram de dois níveis de condutividade elétrica da água de irrigação - $\mathrm{CEa}\left(0,8\right.$ e $\left.4,5 \mathrm{dS} \mathrm{m}^{-1}\right)$ e quatro doses de nitrogênio - DN (70; 85; 100 e $115 \%$ da recomendação). A dose referente a $100 \%$ correspondeu a 200 $\mathrm{g}$ de $\mathrm{N}_{\text {planta }}{ }^{-1}$ ano $^{-1}$. Condutividade elétrica da água de irrigação de $4,5 \mathrm{dS} \mathrm{m}^{-1}$ resultou em alterações nas trocas gasosas e nos componentes de produção da aceroleira 'BRS 366 Jaburu'. O aumento na concentração intercelular de $\mathrm{CO}_{2}$ refletiu na ocorrência de efeitos não estomáticos sobre a taxa de assimilação de $\mathrm{CO}_{2}$ da aceroleira sob salinidade da água de $4,5 \mathrm{dS} \mathrm{m}^{-1}$. O peso médio dos frutos de aceroleira foi reduzido com doses de $\mathrm{N}$ acima de $85 \%$ da recomendação. Doses de nitrogênio acima de $70 \%\left(140 \mathrm{~g} \mathrm{planta}^{-1}\right)$ intensificaram os efeitos negativos do estresse salino sobre o número total e o peso total de frutos da aceroleira.

Palavras-chave: Malpighia emarginata. Fisiologia. Estresse salino. Nutrição mineral.

\section{Introduction}

West Indian cherry (Malpighia emarginata) is a fruit crop belonging to the Malpighiaceae family, which is mostly cultivated in the Northeastern semi-arid region of Brazil. This versatile crop has a high ascorbic acid content and contains important bioactive compounds such as anthocyanins, carotenoids, phenolic compounds, and natural dyes - compounds that have known actions in the prevention of degenerative diseases (DEMBITSKY et al., 2011).

West Indian cherry has socioeconomic importance as it provides opportunities to diversify local economies, keeps workers in rural areas, and is adapted to diverse types of soil and climate. However, like many other crops, the cultivation of West Indian cherry in the semi-arid areas of Northeast Brazil depends on irrigation management. Irregularity of rainfall in this region, combined with a high evaporative demand, causes a water deficit in plants during most part of the year.

High salinity in water and/or soil is one of the main obstacles to crop production (NUNES et al., 2009). West Indian cherry is considered moderately sensitive to salinity as it has a salinity threshold of $2.5 \mathrm{dS} \mathrm{m} \mathrm{m}^{-1}$, in terms of irrigation water electrical conductivity $(\mathrm{ECW})$, and a relative reduction in production of $9.0 \%$ per unit increase in ECw (RHOADES et al., 1992). Nonetheless, crop sensitivity to salt stress can vary according to various other factors, such as cultivar, types of salts, intensity and duration of stress, crop and irrigation management, edaphoclimatic conditions, and fertilization (DEUNER et al., 2011).

In several regions, the deleterious effects of salinity on crops have been overcome by adopting practices of fertilization management. In this context, mineral nutrition is prominent among the strategies employed to increase crop yield and profitability, with nitrogen being one of the main macronutrients responsible for the improvements achieved (CHAVES et al., 2011). Nitrogen functions in plant metabolism as it has a structural role in the synthesis of amino acids, proteins, coenzymes, nucleic acids, vitamins, and chlorophyll - organic compounds that are fundamental for plant survival (CANTARELLA, 2007).

Nitrogen is also an essential component of several biochemical reactions that are necessary for plant metabolism. It is an activator of various enzymatic systems, many of which participate in photosynthesis and respiration, and thereby stimulate growth (EPSTEIN; BLOOM, 2006). Studies carried out in other crops have demonstrated the positive effects of nitrogen fertilization on the growth and development of plants irrigated with saline water, 
for example in sunflower (NOBRE et al., 2010), cowpea (FURTADO et al., 2014), jatropha (LIMA et al., 2015), guava (BEZERRA et al., 2018a), and West Indian cherry (SÁ et al., 2017; MELO et al., 2018).

Currently, there is a need to define a nitrogen dose that meets the nutritional requirements of West Indian cherry cv. 'BRS 366 Jaburu' in the post-grafting stage, and mitigates the deleterious effects of saline water irrigation. The aim of this study was therefore to evaluate the gas exchanges and production of West Indian cherry cv. 'BRS 366 Jaburu' in the post-grafting stage, as a function of irrigation with water of different levels of salinity and fertilization with different doses of nitrogen.

\section{Material and Methods}

This experiment was carried out from June 2017 to July 2018 at the Center of Technology and Natural Resources of the Federal University of Campina Grande (CTRN/UFCG), located in the municipality of Campina Grande, $\mathrm{PB}$, Brazil $\left(7^{\circ} 15^{\prime}\right.$ 18 " S, 35 $55^{\circ}$ ' 28" W; altitude: $550 \mathrm{~m}$ ). Plants were raised under greenhouse conditions, in pots adapted as drainage lysimeters.
The experimental design was randomized blocks with three replicates, using a $2 \times 4$ factorial arrangement. Treatments consisted of two levels of irrigation water electrical conductivity (ECw): 0.8 and $4.5 \mathrm{dS} \mathrm{m}^{-1}$, and four nitrogen doses: $70,85,100$, and $115 \%$ of the recommended dose (CAVALCANTI, 2008). The $100 \%$ dose corresponded to $200 \mathrm{~g}$ of $\mathrm{N}$ per plant per year.

Saline irrigation waters were prepared by dissolving $\mathrm{NaCl}, \mathrm{CaCl}_{2} \cdot 2 \mathrm{H}_{2} \mathrm{O}$, and $\mathrm{MgCl}_{2} \cdot 6 \mathrm{H}_{2} \mathrm{O}$, in equivalent proportion of 7:2:1 respectively, in water from the public supply system. The public supply water of the municipality of Campina Grande, PB, has an $\mathrm{ECw}$ of $0.6 \mathrm{dS} \mathrm{m}^{-1}$, the quantity of salts to be added was based on the relationship between $\mathrm{ECw}$ and the concentration of salts $\left(\mathrm{mmol}_{\mathrm{c}} \mathrm{L}^{-1}=10 * \mathrm{ECW}\right.$ $\mathrm{dS} \mathrm{m}^{-1}$ ) (RICHARDS, 1954).

Lysimeters were filled with a 1-kg layer of crushed stone (Type 0), followed by $250 \mathrm{~kg}$ of a sandy loam Entisol from the rural area of the municipality of Esperança, PB. The soil was properly pounded to break up clods. Prior to the experiment, the soil was sampled to determine its physicochemical characteristics (Table 1) according to the methodology proposed by Donagema et al. (2011). This was carried out in the Laboratory of Irrigation and Salinity (LIS) of CTRN/UFCG.

Table 1. Physical and chemical characteristics of the soil used in the experiment.

\begin{tabular}{|c|c|c|c|c|c|c|c|c|}
\hline \multicolumn{9}{|c|}{ Chemical characteristics } \\
\hline $\mathrm{pH}\left(\mathrm{H}_{2} \mathrm{O}\right)$ & $\mathrm{OM}$ & $\mathrm{P}$ & $\mathrm{K}^{+}$ & $\mathrm{Na}^{+}$ & $\mathrm{Ca}^{2+}$ & $\mathrm{Mg}^{2+}$ & $\mathrm{Al}^{3+}$ & $\mathrm{H}^{+}$ \\
\hline$(1: 2.5)$ & $\mathrm{g} \mathrm{kg}^{-1}$ & $\mathrm{mg} \mathrm{kg}^{-1}$ & \multicolumn{6}{|c|}{ 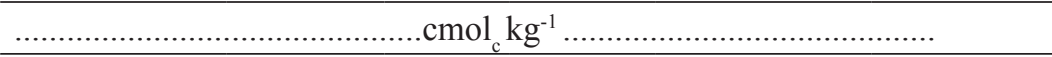 } \\
\hline 5.58 & 2.93 & 39.2 & 0.23 & 1.64 & 9.07 & 2.78 & 0.00 & 8.61 \\
\hline \multicolumn{4}{|c|}{.......... Chemical characteristics............ } & \multicolumn{5}{|c|}{ 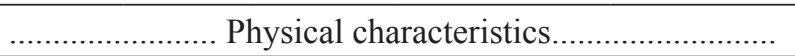 } \\
\hline $\mathrm{CEC}$ & ESP & ECse & SAR & \multicolumn{3}{|c|}{ Size fraction $\left(\mathrm{g} \mathrm{kg}^{-1}\right)$} & \multicolumn{2}{|c|}{ Water content - dag kg-1 } \\
\hline $\mathrm{cmol}_{\mathrm{c}} \mathrm{kg}^{-1}$ & $(\%)$ & $\mathrm{dS} \mathrm{m}^{-1}$ & $\left(\mathrm{mmol} \mathrm{L}^{-1}\right)^{0.5}$ & Sand & Silt & Clay & $33.42 \mathrm{kPa}^{1}$ & $1519.5 \mathrm{kPa}$ \\
\hline 22.33 & 7.34 & 2.15 & 0.67 & 572.7 & 100.7 & 326.6 & 25.91 & 12.96 \\
\hline
\end{tabular}

$\mathrm{pH}$ - hydrogen potential, OM - Organic matter: Walkley-Black Wet Digestion; $\mathrm{Ca}^{2+}$ and $\mathrm{Mg}^{2+}$ extracted with $1 \mathrm{M} \mathrm{KCl}$ at $\mathrm{pH} 7.0 ; \mathrm{Na}^{+}$ and $\mathrm{K}^{+}$extracted using $1 \mathrm{M} \mathrm{NH}_{4} \mathrm{OAc} 1 \mathrm{M}$ at $\mathrm{pH} 7.0 ; \mathrm{Al}^{3+}+\mathrm{H}^{+}$extracted using $0,5 \mathrm{M} \mathrm{CaOAc}$ at $\mathrm{pH} 7.0$; ECse - electrical conductivity of the saturation extract; CEC - Cation exchange capacity; SAR - Sodium adsorption ratio - $(\text { mmol L-1 })^{0.5}$; ESP - Exchangeable sodium percentage. 
A drain was installed at the bottom of each lysimeter using a 4-mm-diameter tube. This was used to drain excess water into a container for evaluation, and to determine plant water consumption. The top of the drain inside the pot was covered with a nonwoven geotextile (Bidim OP 30) to avoid it being clogged by soil.

The rootstock used in this study were West Indian cherry Crioula seedlings provided by EMBRAPA Tropical Agroindustry, located in Pacajus-CE. At transplanting, the seedlings were 240 days old. During the acclimation period in the greenhouse the plants were irrigated with low-salinity water $(0.8$ $\mathrm{dS} \mathrm{m}^{-1}$ ). The scion variety used was cv. 'BRS 366 Jaburu'. This cultivar is notable for its high yield (57 $\left.\mathrm{t} \mathrm{ha}^{-1}\right)$, and content of vitamin C (2,648 mg 100 $\left.\mathrm{g}^{-1}\right)$, plants are around $1.87 \mathrm{~m}$ tall, with a crown diameter of $2.18 \mathrm{~m}$. Fruits of this cultivar are shiny when ripe; they have an average weight of 4 to 5 $\mathrm{g}$ when unripe, appropriate for obtaining vitamin $\mathrm{C}$, and an average weight of 6 to $7 \mathrm{~g}$ after ripening (EMBRAPA, 2012).

Before transplanting of seedlings, soil was brought to field capacity using the saline water of the respective treatments. After transplanting, plants were irrigated every day by applying a volume of water sufficient to maintain soil moisture at close to field capacity. The volume applied was determined according to the water requirement of the plants, as estimated by water balance, i.e., volume applied, minus volume drained in the previous irrigation, plus a leaching fraction of 0.10 .

Fertilization with potassium and phosphorus was also carried out as recommended by Cavalcanti (2008), by applying the equivalent to 200 and 120 g per plant per year, of $\mathrm{K}_{2} \mathrm{O}$ and $\mathrm{P}_{2} \mathrm{O}_{5}$ respectively. Phosphorus was applied entirely as top-dressing, whereas potassium was split into 12 equal portions, and applied monthly. The sources of potassium, phosphorus, and nitrogen were potassium chloride, monoammonium phosphate, and urea, respectively. To meet micronutrient requirements, the leaves of
West Indian cherry plants were sprayed weekly on their adaxial and abaxial sides with a $1.5 \mathrm{~g} \mathrm{~L}^{-1}$ solution of Ubyfol [(N (15\%); $\mathrm{P}_{2} \mathrm{O}_{5}(15 \%) ; \mathrm{K}_{2} \mathrm{O}$ (15\%); Ca (1\%); Mg (1.4\%); S (2.7\%); Zn (0.5\%); $\mathrm{B}(0.05 \%) ; \mathrm{Fe}(0.5 \%) ; \mathrm{Mn}(0.05 \%) ; \mathrm{Cu}(0.5 \%) ; \mathrm{Mo}$ $(0.02 \%)]$.

The gas exchanges of West Indian cherry plants, stomatal conductance $\left(g s, \mathrm{~mol} \mathrm{H}_{2} \mathrm{O} \mathrm{m}^{-2} \mathrm{~s}^{-1}\right)$,

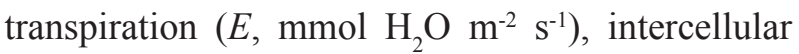
$\mathrm{CO}_{2}$ concentration $\left(\mathrm{Ci}, \mu \mathrm{mol} \mathrm{mol}^{-1}\right)$, and $\mathrm{CO}_{2}$ assimilation rate $\left(A, \mu \mathrm{mol} \mathrm{m} \mathrm{m}^{-2} \mathrm{~s}^{-1}\right)$, were evaluated in fully expanded and unshaded leaves. The third leaf from the apex of each branch was analysed using a portable photosynthesis meter "LCPro+" from ADC BioScientific Ltd. This meter has a photosynthetic photon flux density of $1.200 \mu \mathrm{mol}$ $\mathrm{m}^{-2} \mathrm{~s}^{-1} \cdot \mathrm{CO}_{2}$ assimilation rate and intercellular $\mathrm{CO}_{2}$ concentration data were used to determine carboxylation efficiency (A/Ci) $\left[\left(\mu \mathrm{mol} \mathrm{m}^{-2} \mathrm{~s}^{-1}\right)\right.$

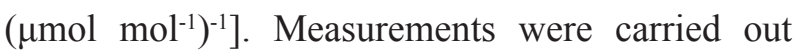
during the transition from the flowering to fruiting stages of the second production cycle, between 7:00 and 9:00 a.m.

Production components were quantified in the second production cycle, as the total number of fruits per plant (TNF), total weight of fruits (TWF), mean weight of fruits (MWF), equatorial diameter (EDF) and polar diameter of fruits (PDF). TWF was determined using an electronic scale with 0.01 g precision, whereas EDF and PDF were measured with a digital caliper.

The data obtained in this study were subjected to an analysis of variance by $\mathrm{F}$ test. When a significant effect was found, a means comparison test (Tukey at 0.05 probability level) was performed for water salinity levels, and a regression analysis was conducted for nitrogen doses. When the interaction between factors (SL $\times \mathrm{ND}$ ) was found to be significant, salinity levels (SL) were further analysed relative to each nitrogen dose (ND) using the statistical program SISVAR-ESAL (FERREIRA, 2011). 


\section{Results and Discussion}

According to the analysis of variance (Table 2), salinity levels had a significant effect $(\mathrm{p}<0.01)$ on stomatal conductance $(g s)$, leaf transpiration $(E)$, intercellular $\mathrm{CO}_{2}$ concentration $(C i), \mathrm{CO}_{2}$ assimilation rate $(A)$ and instantaneous carboxylation efficiency (CEi) in West Indian cherry cv. 'BRS 366
Jaburu'. There was no significant effect $(\mathrm{p}>0.05)$ of $\mathrm{N}$ doses, or of the interaction between factors (SL $\times$ ND), on any of the analysed variables. Similarly, Sá et al. (2017), studying the effects of irrigation with saline water and $\mathrm{N}$ doses, found no significant influence of the interaction between factors (SL $\times$ $\mathrm{N}$ doses) on any of the variables evaluated, 45 days after transplanting.

Table 2. Summary of analysis of variance for stomatal conductance $(g s)$, leaf transpiration $(E)$, intercellular $\mathrm{CO}_{2}$ concentration $(\mathrm{Ci}), \mathrm{CO}_{2}$ assimilation rate $(A)$ and instantaneous carboxylation efficiency (CEi) of West Indian cherry cv. 'BRS 366 Jaburu' under irrigation with water of different salinity levels and nitrogen doses.

\begin{tabular}{lcccccc}
\hline \multirow{2}{*}{ Source of variation } & \multirow{2}{*}{ DF } & \multicolumn{5}{c}{ Mean squares } \\
\cline { 3 - 6 } & & $g s$ & $E$ & $C i$ & $A$ & $C E i$ \\
\hline Saline levels (SL) & 1 & $0.14^{* *}$ & $5.38^{* *}$ & $153440.04^{* *}$ & $89.66^{* *}$ & $0.007^{* *}$ \\
Nitrogen doses (ND) & 3 & $0.003^{\text {ns }}$ & $0.13^{\text {ns }}$ & $430.15^{\text {ns }}$ & $0.75^{\text {ns }}$ & $0.00003^{\text {ns }}$ \\
$\quad$ Linear regression & 1 & $0.0006^{\text {ns }}$ & $0.008^{\text {ns }}$ & $686.40^{\text {ns }}$ & $1.11^{\text {ns }}$ & $0.000001^{\text {ns }}$ \\
Quadratic regression & 1 & $0.002^{\text {ns }}$ & $0.06^{\text {ns }}$ & $1.04^{\text {ns }}$ & $0.96^{\text {ns }}$ & $0.00002^{\text {ns }}$ \\
Interaction (NS x ND) & 3 & $0.003^{\text {ns }}$ & $0.06^{\text {ns }}$ & $425.81^{\text {ns }}$ & $4.46^{\text {ns }}$ & $0.0001^{\text {ns }}$ \\
Blocks & 2 & $0.003^{\text {ns }}$ & $0.09^{\text {ns }}$ & $1482.00^{\text {ns }}$ & $2.43^{\text {ns }}$ & $0.00008^{\text {ns }}$ \\
Residual & 14 & 0.01 & 0.16 & 639.61 & 0.86 & 0.00006 \\
CV (\%) & & 27.34 & 36.56 & 10.08 & 16.59 & 27.17 \\
\hline
\end{tabular}

ns, $* *$, respectively not significant and significant at $\mathrm{p}<0.01 ; \mathrm{CV}$ - coefficient of variation; DF - degrees of freedom.

The salinity level of irrigation water significantly influenced stomatal conductance $(g s)$ in West Indian cherry cv. 'BRS 366 Jaburu'. According to the comparison test of means (Figure 1A), plants cultivated under the lower ECw level $\left(0.8 \mathrm{dS} \mathrm{m}^{-1}\right)$ demonstrated the highest value of $g s(0.188 \mathrm{~mol}$ $\mathrm{H}_{2} \mathrm{O} \mathrm{m}^{-2} \mathrm{~s}^{-1}$ ), and this was significantly different to the $g s$ values of plants subjected to the higher water salinity of $4.5 \mathrm{dS} \mathrm{m}^{-1}$. A comparison between the $g s$ values of plants irrigated with ECw of $4.5 \mathrm{dS} \mathrm{m}^{-1}$ and the $g s$ values of those subjected to $0.8 \mathrm{dS} \mathrm{m}^{-1}$ showed that the imposition of salt stress led to a reduction in $g s$ of $0.156 \mathrm{~mol} \mathrm{H}_{2} \mathrm{O} \mathrm{m}^{-2} \mathrm{~s}^{-1}$. This reduction in gs may have contributed to stomatal closure and a consequent reduction in normal $\mathrm{CO}_{2}$ flow toward the carboxylation site. This is one of the main causes of reductions in photosynthesis, with water also being one of the fundamental factors regulating stomatal opening and closing (BOSCO et al., 2009). Sá et al. (2017), in a study evaluating the effects of $\mathrm{N}$ and $\mathrm{P}$ fertilization on the gas exchanges of West Indian cherry irrigated with water of different salinities ( $\mathrm{ECw}$ from 0.6 to $3.8 \mathrm{dS} \mathrm{m}^{-1}$ ), also observed a reduction in stomatal conductance as the electrical conductivity of irrigation water increased, 45 days after transplanting.

Irrigation with saline water caused a noticeable reduction in the leaf transpiration $(E)$ of West Indian cherry cv. 'BRS 366 Jaburu'. The $E$ of plants irrigated with the higher level of ECw $\left(4.5 \mathrm{dS} \mathrm{m}^{-1}\right)$ was statistically different to those subjected to a lower water salinity of $0.8 \mathrm{dS} \mathrm{m} \mathrm{m}^{-1}$. Based on the means comparison test (Figure 1B), plants subjected to ECW of $4.5 \mathrm{dS} \mathrm{m}^{-1}$ showed a reduction in $E$ of $0.95 \mathrm{mmol} \mathrm{H}_{2} \mathrm{O} \mathrm{m}^{-2} \mathrm{~s}^{-1}$ in comparison to those 
irrigated with low-salinity water $\left(0.8 \mathrm{dS} \mathrm{m}^{-1}\right)$. This for physiological processes (TÁVORA et al., 2001). reduction in $E$ is probably related to these plants deploying stomatal closure as a strategy to maintain a high cell water potential and reduce the absorption of toxic ions - especially $\mathrm{Na}^{+}$and $\mathrm{Cl}^{-}$(Figure 1A). Nonetheless, this reduction in transpiration has direct consequences on both the absorption of nutrients, and the transport and redistribution of elements important Dias et al. (2018), evaluating gas exchanges and photochemical efficiency of West Indian cherry in the post-grafting stage, also found that water salinity inhibited leaf transpiration and recorded a reduction in $E$ of $0.412 \mathrm{mmol}$ of $\mathrm{H}_{2} \mathrm{O} \mathrm{m}^{-2} \mathrm{~s}^{-1}$ in plants under the highest salinity level $\left(3.8 \mathrm{dS} \mathrm{m}^{-1}\right)$, compared to those subjected to ECw of $0.8 \mathrm{dS} \mathrm{m}^{-1}$.

Figure 1. Stomatal conductance - $g s(\mathrm{~A})$, leaf transpiration foliar - $E(\mathrm{~B})$, intercellular $\mathrm{CO}_{2}$ concentration - $\mathrm{Ci}(\mathrm{C}) \mathrm{CO}_{2}$ assimilation rate - $A$ (D) and instantaneous carboxylation efficiency - CEi (E) of West Indian cherry cv. 'BRS 366 Jaburu' under irrigation with water of different salinity levels - ECw.
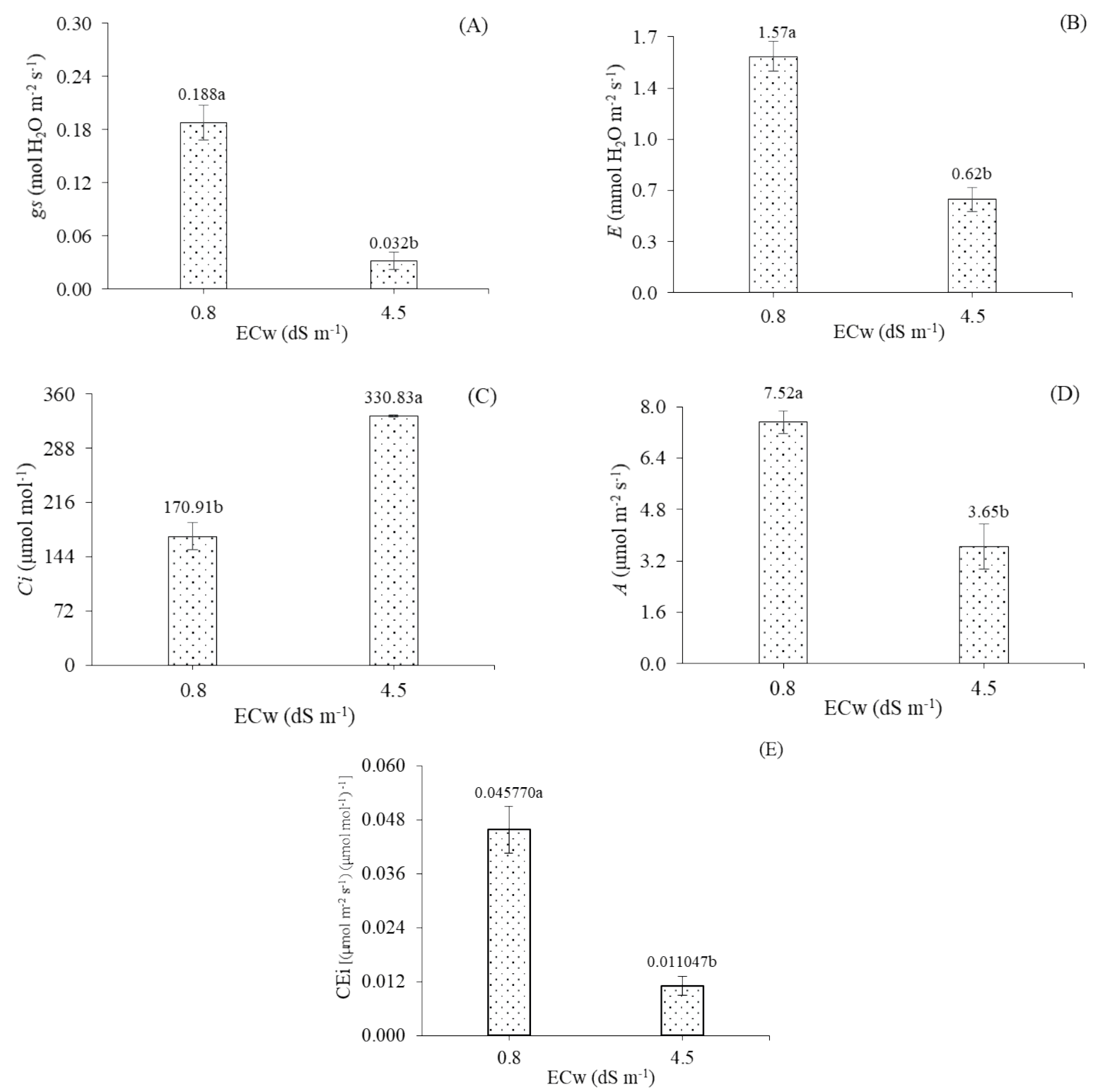

Bars represent the standard error of the mean $(n=3)$. Means followed by different letters indicate significant difference between treatments by Tukey test, $\mathrm{p}<0.05$. 
Contrary to the situation observed for stomatal conductance and leaf transpiration (Figures 1A$\mathrm{B})$, the intercellular $\mathrm{CO}_{2}$ concentration $(\mathrm{Ci})$ of West Indian cherry plants sharply increased in those irrigated with the irrigation water with higher electrical conductivity. According to the means comparison test (Figure 1C), the intercellular $\mathrm{CO}_{2}$ concentration of plants irrigated with $\mathrm{ECw}$ of $0.8 \mathrm{dS} \mathrm{m}^{-1}$ was significantly different to those irrigated with $4.5 \mathrm{dS} \mathrm{m}^{-1}$ water. Notably, plants irrigated with $0.8 \mathrm{dS} \mathrm{m}^{-1}$ water showed a reduction in intercellular $\mathrm{CO}_{2}$ concentration of $159.92 \mu \mathrm{mol} \mathrm{mol}^{1}$, compared to those subjected to $4.5 \mathrm{dS} \mathrm{m}^{-1}$ (Figure 1C). By comparing the means of the $\mathrm{CO}_{2}$ assimilation rates $(A)$ of each treatment (Figure 1D), it is evident that West Indian cherry plants irrigated with water of lower ECw $(0.8 \mathrm{dS}$ $\left.\mathrm{m}^{-1}\right)$ showed a higher $A\left(7.52 \mu \mathrm{mol} \mathrm{m} \mathrm{m}^{-2} \mathrm{~s}^{-1}\right)$, and this differed significantly from the $A$ of plants subjected to the higher water salinity level.

The means comparison test (Figure 1D) also demonstrated that West Indian cherry plants, when irrigated with $4.5 \mathrm{dS} \mathrm{m}^{-1}$ water, showed a $3.87 \mu \mathrm{mol}$ $\mathrm{m}^{-2} \mathrm{~s}^{-1}$ reduction in $\mathrm{CO}_{2}$ assimilation rate compared with plants irrigated with low-salinity water $\left(0.8 \mathrm{dS} \mathrm{m}^{-1}\right)$. This reduction in $\mathrm{CO}_{2}$ assimilation rate may be due to the action of various factors, specifically, the dehydration of cell membranes (reducing permeability to $\mathrm{CO}_{2}$ ), and ionic toxicity (especially by $\mathrm{Na}^{+}$and $\mathrm{Cl}^{-}$) (ROHANIPOOR et al., 2013).

According to Zhou et al. (2013), a reduction in the $\mathrm{CO}_{2}$ assimilation rate is generally caused by stomatal limitation under moderate stress conditions in which $g s$ and $\mathrm{Ci}$ decrease. This was not observed in our study, where non-stomatal limitation was the main reason for a reduction in photosynthesis when $\mathrm{Ci}$ increased (Figure 1C) and $g_{s}$ (Figure 1A) reached a minimum point of inflection. Xu et al. (2008) stated that osmotic effects induced by increased salinity may adversely affect the activities of various enzymes involved in the reduction of $\mathrm{CO}_{2}$. Likewise, Bezerra et al. (2018b) observed a reduction in the assimilation rate of $\mathrm{CO}_{2}$ in guava plants because of increased soil salinity (ECw ranging from 2.15 to $6.15 \mathrm{dS}$ $\mathrm{m}^{-1}$ ). These authors attributed this reduction to high concentrations of ions such as $\mathrm{Na}^{+}$and $\mathrm{Cl}^{-}$. These ions can cause damage to the structure of enzymes and membranes, thereby indirectly interfering with the $\mathrm{CO}_{2}$ assimilation rate.

Instantaneous carboxylation efficiency (CEi) (Figure 1E) is a parameter used to identify the actions of non-stomatal factors. Such factors can interfere with the $\mathrm{CO}_{2}$ assimilation rate, and are directly related to net photosynthesis and the intercellular $\mathrm{CO}_{2}$ concentration of the substomatal chamber (SUASSUNA et al., 2014). The means comparison test (Figure 1E) showed that West Indian cherry plants cultivated under the higher level of water salinity $\left(4.5 \mathrm{dS} \mathrm{m}^{-1}\right)$ had a reduction in CEi of $75.87 \%$ [ $\left(0.034723 \mu \mathrm{mol} \mathrm{m} \mathrm{m}^{-2} \mathrm{~s}^{-1}\right)(\mu \mathrm{mol}$ $\left.\mathrm{mol}^{-1}\right)^{-1}$ ] in comparison to those subjected to water with an electrical conductivity of $0.8 \mathrm{dS} \mathrm{m}^{-1}$. This reduction of instantaneous carboxylation efficiency is probably associated with a reduction in the activity of ribulose-1,5-bisphosphate carboxylaseoxygenase (RuBisCO) due to an accumulation of salts in leaf tissues, especially $\mathrm{Na}^{+}$and $\mathrm{Cl}^{-}$ (SILVA et al., 2011). These salts, along with other environmental factors, favor the oxygenation of $\mathrm{RuBisCO}$ and an increase in the photorespiratory pathway, resulting in a significant reduction in carbon compounds (VOSS et al., 2013).

The analysis of variance (Table 3) revealed that changes in water salinity caused significant differences in the total weight (TWF) and total number of fruits (TNF) per plant $(p<0.01)$, and in the equatorial (EDF) and polar diameter of fruits $(p \leq 0.05)$ of West Indian cherry $c v$. 'BRS 366 Jaburu'. Furthermore, dose of nitrogen had a significant effect on TNF, TWF, mean weight of fruit (MWF), and EDF, whereas the interaction between factors $(\mathrm{SL} \times \mathrm{ND})$ only had a significant 
influence on TNF and TWF. Lima et al. (2018), studying the same cultivar of West Indian cherry under irrigation with saline water (ECw from 0.8 to $3.8 \mathrm{dS} \mathrm{m}^{-1}$ ) and with potassium doses $(\mathrm{KD})$, also found a significant effect of the interaction between factors $(\mathrm{SL} \times \mathrm{KD})$ on the total number and weight of fruits per plant.

Table 3. Summary of analysis of variance for total number of fruits per plant (TNF), total weight of fruits (TWF), mean weight of fruits (MWF), equatorial diameter (EDF) and polar diameter of fruits (PDF) of West Indian cherry cv. 'BRS 366 Jaburu' under irrigation with water of different salinity levels and nitrogen doses.

\begin{tabular}{lcccccc}
\hline \multirow{2}{*}{ Source of variation } & \multirow{2}{*}{ DF } & \multicolumn{5}{c}{ Mean squares } \\
\cline { 3 - 6 } & & NTF & TWF & MWF & EDF & PDF \\
\hline Saline levels (SL) & 1 & $705722.51^{* *}$ & $16254381.71^{* *}$ & $1.05^{\text {ns }}$ & $176.71^{*}$ & $110.89^{*}$ \\
Nitrogen doses (ND) & 3 & $68779.51^{* *}$ & $766263.37^{*}$ & $7.26^{*}$ & $27.44^{*}$ & $12.75^{\text {ns }}$ \\
$\quad$ Linear regression & 1 & $757.51^{\text {ns }}$ & $642163.36^{*}$ & $4.10^{*}$ & $38.48^{*}$ & $32.31^{\text {ns }}$ \\
Quadratic regression & 1 & $120487.51^{*}$ & $105913.33^{\text {ns }}$ & $6.72^{*}$ & $3.55^{\text {ns }}$ & $2.76^{\text {ns }}$ \\
Interaction (NS x ND) & 3 & $73858.17^{* *}$ & $653416.92^{*}$ & $0.57^{\text {ns }}$ & $32.07^{\text {ns }}$ & $13.81^{\text {ns }}$ \\
Blocks & 2 & $8795.38^{\text {ns }}$ & $40663.12^{\text {ns }}$ & $0.06^{\text {ns }}$ & $0.61^{\text {ns }}$ & $2.51^{\text {ns }}$ \\
Residual & 14 & 6098.88 & 197866.83 & 0.06 & 8.02 & 10.56 \\
CV $(\%)$ & & 11.97 & 18.00 & 17.37 & 12.10 & 15.74 \\
\hline
\end{tabular}

ns, ${ }^{* *}, *$ respectively not significant, significant at $\mathrm{p}<0.01$ and $\mathrm{p}<0.05 ; \mathrm{CV}$ - coefficient of variation; DF - degrees of freedom.

The total number of fruits of West Indian cherry cv. 'BRS 366 Jaburu' was significantly affected by the interaction between factors $(\mathrm{SL} \times \mathrm{ND})$, with a quadratic model of regression (Figure 2A) fitting the data obtained from plants irrigated with $\mathrm{ECW}$ of 0.8 and $4.5 \mathrm{dS} \mathrm{m}^{-1}$. For plants cultivated with the lower salinity level $\left(0.8 \mathrm{dS} \mathrm{m}^{-1}\right)$, the greatest number of fruits was obtained when $\mathrm{N}$ doses of $101 \%$ were used (922.67 fruits per plant). However, West Indian cherry plants subjected to a water salinity of $4.5 \mathrm{dS}$ $\mathrm{m}^{-1}$ had a drastic reduction in TNF with increasing supply of $\mathrm{N}$, with a maximum estimated value of 740.08 fruits per plant in plants that received $70 \%$ of the recommended $\mathrm{N}$ dose (CAVALCANTI, 2008). Thus, it can be inferred that an increased dose of $\mathrm{N}$, in association with a higher level of ECw, intensified the deleterious effects of salt stress on West Indian cherry. A reduction in the number of fruits per plant under salt stress may be associated with an excess absorption and transportation of $\mathrm{Na}^{+}$ ions to the shoots. Excess $\mathrm{Na}^{+}$ions could possibly occupy the absorption sites of $\mathrm{K}^{+}$and $\mathrm{Mg}^{2+}$, while excess $\mathrm{Cl}^{-}$could act in the sites of $\mathrm{N}$ and $\mathrm{P}$, thereby inhibiting their absorption due to competitive mechanisms (LUCENA et al., 2012). Lima et al. (2018) also observed a reduction in the production of West Indian cherry fruits because of irrigation with saline water. However, these authors observed that the deleterious effects of salinity on the total number of fruits could be mitigated by potassium fertilization. 
Figure 2. Total number of fruits per plant - TNF (A) and total weight of fruits - TWF (B) of West Indian cherry cv. 'BRS 366 Jaburu' as a function of the interaction between the levels of water salinity and nitrogen doses.

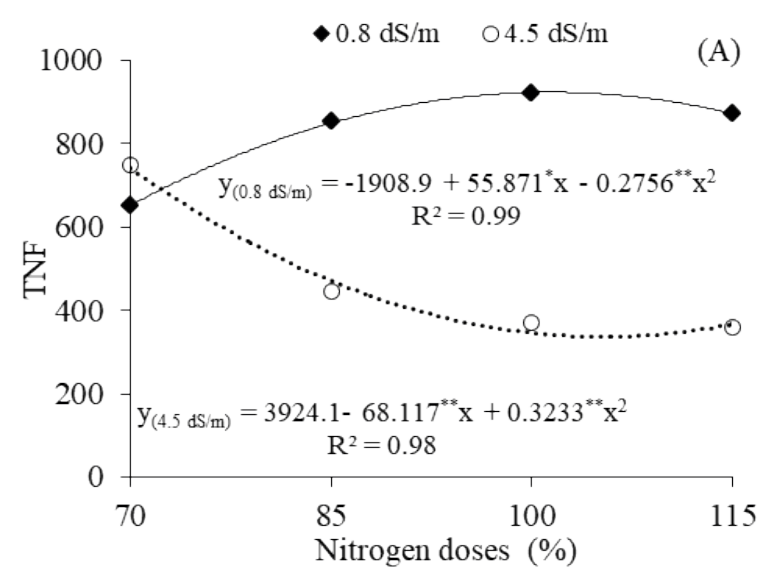

The total weight of West Indian cherry fruits was also influenced by the interaction between factors, salinity levels and $\mathrm{N}$ doses. According to the regression equations (Figure $2 \mathrm{~B}$ ), the variation in TWF showed a similar trend to that of TNF. When irrigated with the water with lower ECw and with $\mathrm{N}$ doses equivalent to $85 \%$ of recommendation, West Indian cherry plants produced the greatest TWF, with a maximum estimated value of $3658.95 \mathrm{~g}$ per plant. TWF decreased at higher doses of $\mathrm{N}$, and reached the lowest values in plants that received $115 \%$ of recommendation (2700.75 g per plant). However, West Indian cherry plants irrigated with water with an $\mathrm{ECw}$ of $4.5 \mathrm{dS} \mathrm{m}^{-1}$ showed a greater reduction in the total weight of fruits, and the maximum estimated value for this variable $(2339.40 \mathrm{~g}$ per plant) was obtained at $70 \%$ of the recommended dose of $\mathrm{N}$. This reduction in the total weight of fruits per plant may be a reflection of the reduction observed in the total number of fruits (Figure 2A), or a consequence of excess salts interfering in the $\mathrm{CO}_{2}$ assimilation process (Figure 1D). Alternatively, it may relate to the reduction in the osmotic potential of the soil solution, which affects negatively the absorption of water and nutrients by plants. This reduction results in the partial use of carbohydrates in other metabolic pathways (ABDELHAMID et al., 2013), such as in the synthesis of compatible solutes (trehalose, glycine betaine, proline, among

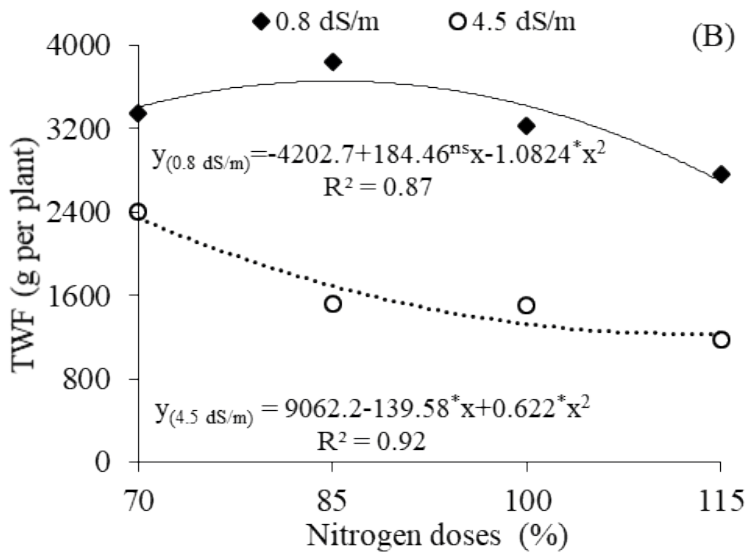

others), the repair of oxidative damage caused by salt stress, and the maintenance of cell homeostasis (PARANYCHIANAKIS; CHARTZOULAKIS, 2005). It is possible that such a scenario contributed to a reduction in the translocation of photoassimilates to the production components (TNF and TWF) of West Indian cherry.

Nitrogen doses significantly influenced the mean weight of fruits of West Indian cherry cv. 'BRS 366 Jaburu'. According to the regression analysis (Figure 3), the greatest MWF (4.405 g per fruit) was obtained with a $\mathrm{N}$ dose corresponding to $83 \%$ of the recommendation (CAVALCANTI, 2008); doses greater than this caused a drastic reduction in MWF, with a minimum weight of $1.855 \mathrm{~g}$ per fruit in plants that received a $\mathrm{N}$ dose of $115 \%$. There was a reduction of $2.18 \mathrm{~g}$ per fruit in the MWF of plants under the dose of $115 \% \mathrm{~N}$ compared with those under $70 \%$ of the $\mathrm{N}$ recommendation. Based on the data recommended by EMBRAPA for the cultivar 'BRS 366 Jaburu' (ripe fruit mean weight of 6 to 7 g), the MWF obtained in this study was lower (1.855 to $4.405 \mathrm{~g}$ ). Thus, it is possible that a supply of $\mathrm{N}$ above the recommended dose intensified the effect of salt stress on West Indian cherry plants, because of the salt index of the fertilizer used (75). Oliveira et al. (2014), in a study evaluating the production of eggplant fruits as a function of irrigation water of different salinities (ECW of 0.5 and $6.0 \mathrm{dS} \mathrm{m}^{-1}$ ) 
in association with $\mathrm{N}$ doses, concluded that high $\mathrm{N}$ doses cause a reduction in yield and intensify the deleterious effects of irrigation water salinity.

The equatorial diameter of West Indian cherry fruits decreased significantly as the salinity of irrigation water increased; according to the means comparison test (Figure 4A), the EDF in plants irrigated with the higher level of electrical conductivity $\left(4.5 \mathrm{dS} \mathrm{m}^{-1}\right)$ differed significantly from that of plants cultivated under the lower salinity level $\left(0.8 \mathrm{dS} \mathrm{m}^{-1}\right)$. By comparing the data obtained from plants cultivated under $\mathrm{ECW}$ of $4.5 \mathrm{dS} \mathrm{m}^{-1}$ with those of plants subjected to the lower salinity level, there was a reduction of $5.42 \mathrm{~mm}$ in the EDF. Thus, the data obtained for EDF are consistent with the results of TNF and TWF, in that irrigation water salinity caused a reduction in the number and total weight of fruits (Figure 4A) as well as a reduction in the size of fruit (on the basis of equatorial diameter). A decrease in fruit diameter can also be related to the effects of increased salinity. Alterations in the osmotic potential of the soil solution due to a high concentration of soluble salts in the root zone can cause a reduction in water and nutrient consumption by plants, thus resulting in the formation of fruits with smaller diameters (LEONARDO et al., 2008). Sá (2018) found that in West Indian cherry plants under high salinity conditions $\left(3.8 \mathrm{dS} \mathrm{m} \mathrm{m}^{-1}\right)$ there were reductions not only in fruit production, but also in the weight and diameter of fruit, due to salt stress.

Figure 3. Mean weight of fruits - MWF of West Indian cherry cv. 'BRS 366 Jaburu', as a function of nitrogen doses.

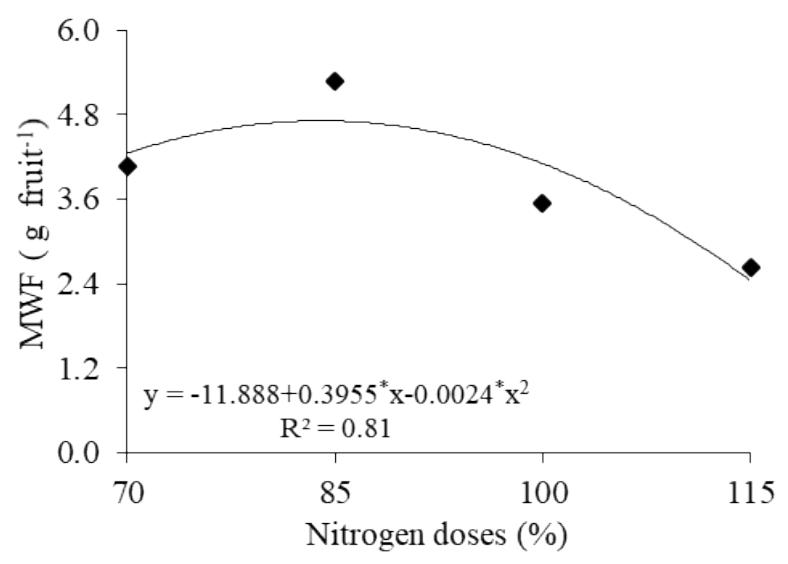

Figure 4. Equatorial diameter - EDF (A) and polar diameter - PDF (B) of fruits of West Indian cherry cv. 'BRS 366 Jaburu' under irrigation with water of different salinity levels - ECw.
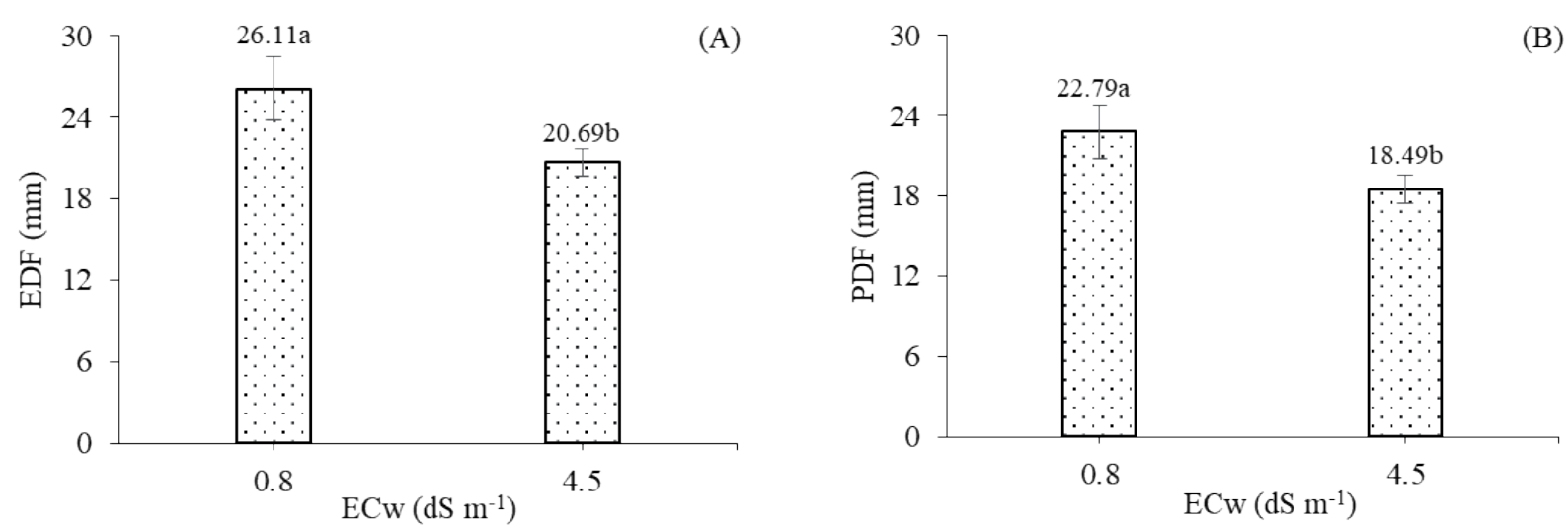

Bars represent the standard error of the mean $(n=3)$. Means followed by different letters indicate significant difference between treatments by Tukey test, $\mathrm{p}<0.05$. 
The increase in the salinity of irrigation water also affected the polar diameter of fruits of West Indian cherry cv. 'BRS 366 Jaburu'. According to the means comparison test (Figure 4B), plants irrigated with $\mathrm{ECw}$ of $0.8 \mathrm{dS} \mathrm{m} \mathrm{m}^{-1}$ produced fruits with larger polar diameters $(22.79 \mathrm{~mm})$. Fruits with smaller diameters $(18.49 \mathrm{~mm})$ were produced in West Indian cherry plants subjected to $\mathrm{ECW}$ of $4.5 \mathrm{dS} \mathrm{m}^{-1}$, i.e., there was a reduction of $4.3 \mathrm{~mm}$ in polar diameter when compared with plants cultivated under a water salinity of $0.8 \mathrm{dS} \mathrm{m}^{-1}$. Thus, it is evident that the osmotic effect of excess salts in the high-salinity irrigation water caused a reduction in availability of water, leading to a water deficit in West Indian cherry plants. This may have caused alterations in ionic homeostasis, probably favoring the translocation of photoassimilates for use in acclimation in plants grown under salt stress (NIVAS et al., 2011) and consequently, these plants produced fruits with a smaller diameter. Bezerra (2018), evaluating the production components and post-harvest quality of 'Paluma' guava irrigated with water of $\mathrm{ECw}$ of 0.3 to $3.5 \mathrm{dS} \mathrm{m}^{-1}$, observed reductions in fruit polar diameters of 7.08 and $7.43 \%$, per unit increase in ECw respectively, in the first and second year of cultivation.

\section{Conclusions}

Irrigation water with electrical conductivity of $4.5 \mathrm{dS} \mathrm{m}^{-1}$ inhibits leaf gas exchanges and reduces production in West Indian cherry cv. 'BRS 366 Jaburu'.

An increase in the concentration of intercellular $\mathrm{CO}_{2}$ is an indication of non-stomatal effects on the $\mathrm{CO}_{2}$ assimilation rate of West Indian cherry plants cultivated under a water salinity of $4.5 \mathrm{dS} \mathrm{m}^{-1}$.

The mean weight of West Indian cherry fruits is reduced when nitrogen doses are above 85\% (170 g plant $^{-1}$ year $^{-1}$ ) of the recommended level.

Nitrogen doses above $70 \%$ of the recommendation $\left(140\right.$ g plant $^{-1}$ year $\left.^{-1}\right)$ intensify the negative effects of salt stress on the total number and weight of West Indian cherry fruits.

\section{Acknowledgments}

To the National Post-doctoral Program (PNPD/ CAPES/UFCG), for granting the scholarship to the first author, and to the National Institute of Science and Technology in Salinity - INCTSal, for funding the project.

\section{References}

ABDELHAMID, M.; SADAK, M. S. H.; SCHMIDHALTER, U.; EL-SAADY, A. K. Interactive effects of salinity stress and nicotinamide on physiological and biochemical parameters of faba bean plant. Acta Biológica Colombiana, Bogotá, v. 18, n. 3, p. 499-510, 2013.

BEZERRA, I. L. Irrigação com águas salinas $e$ adubação nitrogenada no cultivo de goiabeira. 2018. Tese (Doutorado em Engenharia Agrícola) - Universidade Federal de Campina Grande, UFCG, Campina Grande.

BEZERRA, I. L.; GHEYI, H. R.; NOBRE, R. G.; BARBOSA, J. L.; FÁTIMA, R. T. de; ELIAS, J. J.; SOUZA, L. de P.; AZEVEDO, F. L. de. Physiological alterations and production of guava under water salinity and nitrogen fertilizer application. Semina: Ciências Agrárias, Londrina, v. 39, n. 5, p. 1945-1956, 2018 a. DOI: $10.5433 / 1679-0359.2018 v 39 n 5 p 1945$

BEZERRA, I. L.; GHEYI, H. R.; NOBRE, R. G.; LIMA, G. S. de; SANTOS, J. B. dos; FERNANDES, P. D. Interaction between soil salinity and nitrogen on growth and gaseous exchanges in guava. Revista Ambiente \& Água, Taubaté, v. 13, n. 3, p. e2130, 2018b. DOI: 10.4136/ambi-agua. 2130

BOSCO, M. R. O.; OLIVEIRA, A. B.; HERNANDEZ, F. F. F.; LACERDA, C. F. Efeito do $\mathrm{NaCl}$ sobre o crescimento, fotossíntese e relações hídricas de plantas de berinjela. Revista Ceres, Viçosa, v. 56, n. 3, p. 296302. 2009.

CANTARELLA, H. Nitrogênio. In: NOVAIS, R. F.; ALVAREZ, V. V. H.; BARROS, N. F.; FONTES, R. L. F.; CANTARUTTI, R. B.; NEVES, J. C. L. (Ed.). Fertilidade do solo. Viçosa, MG: Sociedade Brasileira de Ciência do Solo, 2007. p. 375-470.

CAVALCANTI, F. J. de A. (Coord.). Recomendações de adubação para o Estado de Pernambuco. 2. aproximação. 2. ed. rev. Recife: IPA, 2008. 212 p. 
CHAVES, L. H. G.; GHEYI, H. R.; RIBEIRO, S. Consumo de água e eficiência do uso para cultivar de mamona Paraguaçu submetida à fertilização nitrogenada. Engenharia Ambiental, Espírito Santo do Pinhal v. 8, n. 1, p. 126-133, 2011.

DEMBITSKY, V.; POOVARODOM, S.; LEONTOWICZ, H.; LEONTOWICZ, M.; VEARASILP, S.; TRAKHTENBERG, S.; GORINSTEIN, S. The multiple nutrition properties of some exotic fruits: biological activity and active metabolites. Food Research International, Ottawa, v. 44, n. 7, p. 1671-1701, 2011. DOI: 10.1016/j.foodres.2011.03.003

DEUNER, C.; MAIA, M.de S.; DEUNER, S.;ALMEIDA, A. da S.; MENEGHELLO, G. E. Viabilidade e atividade antioxidante de sementes de genótipos de feijão-miúdo submetidos ao estresse salino. Revista Brasileira de Sementes, Londrina, v. 33, n. 4, p. 711-720, 2011.

DIAS, A. S.; LIMA G. S. de; SÁ, F. V. da S.; GHEYI, H. R.; SOARES, L. A. dos A.; FERNANDES, P. D. Gas exchanges and photochemical efficiency of West Indian cherry cultivated with saline water and potassium fertilization. Revista Brasileira de Engenharia Agrícola e Ambiental, Campina Grande, v. 22, n. 9, p. 628-633, 2018. DOI: 10.1590/1807-1929/agriambi.v22n9p628-633

DONAGEMA, G. K.; CAMPOS, D. V. B. de; CALDERANO, S. B.; TEIXEIRA, W. G.; VIANA, J. H. M. (Org.). Manual de métodos de análise de solo. 2. ed. Rio de Janeiro: EMBRAPA Solos, 2011. 230 p.

EMPRESA BRASILEIRA DE PESQUISA AGROPECUÁRIA - EMBRAPA. Cultivar acerola BRS 366-Jaburu. Fortaleza: Embrapa Agroindústria Tropical, 2012. 2 p.

EPSTEIN, E.; BLOOM, A. J. Nutrição mineral de plantas: princípios e perspectivas. 2. ed. trad. Londrina: Editora Planta, 2006. 392 p.

FERREIRA, D. F. Sisvar: A computer statistical analysis system. Ciência e Agrotecnologia, Lavras, v. 35, n. 6, p. 1039-1042, 2011. DOI: 10.1590/S141370542011000600001

FURTADO, G. de F.; SOUSA JUNIOR, J. R. de; XAVIER, D. A.; ANDRADE, E. M. G.; SOUSA, J. R. M. de. Pigmentos fotossintéticos e produção de feijão Vigna ungüiculada L. walp sob salinidade e adubação nitrogenada. Revista Verde de Agroecologia e Desenvolvimento Sustentável, Mossoró, v. 9, n. 2, p. 291299, 2014.

LEONARDO, M.; BROETTO, F.; BOAS, R. L. V.; MARCHESE, J. A.; TONIN, F. B.; REGINA, M. Estado nutricional e componentes da produção de plantas de pimentão conduzidas em sistema de fertirrigação durante indução de estresse salino em cultivo protegido. Bragantia, Campinas, v. 67, n. 4, p. 883-889, 2008. DOI: 10.1590/S0006-87052008000400010

LIMA, G. S. de; DIAS, A. S.; SOUZA, L. de P.; SÁ, F. V. da S.; GHEYI, H. R.; SOARES, L. A. dos A. Effects of saline water and potassium fertilization on photosynthetic pigments, growth and production of West Indian cherry. Revista Ambiente \& Água, Taubaté, v. 13, n. 3, p. e2164-x, 2018. DOI: 10.4136/ambi-agua.2164

LIMA, G. S. de; NOBRE, R. G.; GHEYI, H. R.; SOARES, L. A. dos A.; SILVA, A. O. Produção da mamoneira cultivada com águas salinas e doses de nitrogênio. Revista Ciência Agronômica, Fortaleza, v. 46, n. 1, p. 1-10, 2015. DOI: 10.1590/S1806-66902015000100001

LUCENA, C. C. de; SIQUEIRA, D. L. de; MARTINEZ, H. E. P.; CECON, P. R. Efeito do estresse salino na absorção de nutrientes em mangueira. Revista Brasileira de Fruticultura, Jaboticabal, v. 34, n. 1, p. 297-308, 2012. DOI: 10.1590/S0100-29452012000100039

MELO, E. N. de; NOBRE, R. G.; PINHEIRO, F. W. A.; SOUZA, L. de P.; LIMA, G. S. de; GHEYI, H. R.; ELIAS, J. J.; SILVA, W. L. da. Evaluation of West Indian cherry (Malpighia emarginata) rootstock under saline water irrigation and nitrogen fertilization. Australian Journal of Crop Science, Canberra, v. 12, n. 6, p. 10341040, 2018. DOI: 10.21475/ajcs.18.12.06.PNE1314

NIVAS, D.; GAIKWAD, D. K.; CHAVN, P. D. Physiological responses of two morinda species under saline conditions. American Journal of Plant Physiology, New York, v. 6, n. 3, p. 157-166, 2011. DOI: 10.3923/ ajpp.2011.157.166

NOBRE, R. G.; GHEYI, H. R.; CORREIA, K. G.; SOARES, F. A. L.; ANDRADE, L. O. de. Crescimento e floração do girassol sob estresse salino e adubação nitrogenada. Revista Ciência Agronômica, Fortaleza, v. 41, n. 3, p. 358-365, 2010. DOI: 10.1590/S180666902010000300006

NUNES, J. C.; CAVAlCANTE, L. F.; REBEQUI, A. M.; LIMA NETO, A. J. de; DINIZ, A. A.; SILVA, J. J. M.; BREH, M. A. da S. Formação de mudas de noni sob irrigação com águas salinas e biofertilizante bovino no solo. Engenharia Ambiental, Espírito Santo do Pinhal, v. 6, n. 2, p. 451- 463, 2009.

OLIVEIRA, F. de A. de; MEDEIROS, J. F. de; ALVES, R. de C.; LINHARES, P. S. F.; MEDEIROS, A. M. A. de; OLIVEIRA, M. K. T. de. Interação entre salinidade da água de irrigação e adubação nitrogenada na cultura da berinjela. Revista Brasileira de Engenharia Agrícola e Ambiental, Campina Grande, v. 18, n. 5, p. 480-486, 2014. DOI: $10.1590 / \mathrm{S} 1415-43662014000500003$ 
PARANYCHIANAKIS, N. V.; CHARTZOULAKIS, K. $\mathrm{S}$. Irrigation of mediterranean crops with saline water: from physiology to management practices. Agriculture, Ecosystems and Environment, Zurich, v. 106, n. 2-3, p. 171-187, 2005. DOI: 10.1016/j.agee.2004.10.006

RHOADES, J. D.; KANDIAH, A.; MASHALI, A. M. Uso de águas salinas para produção agrícola. Campina Grande: UFPB, 1992. 117 p. (Estudos da FAO, Irrigação e Drenagem, 48).

RICHARDS, L. A. Diagnosis and improvement of saline and alkali soils. Washington: USDA, 1954. 160 p. (USDA, Agriculture Handbook, 60).

ROHANIPOOR, A.; NOROUZI, M.; MOEZZI, A.; HASSIBI, P. Effect of silicon on some physiological properties of maize (Zea mays) under salt stress. Journal of Biodiversity and Environmental Sciences, Bangladesh, v. 7, n. 20, p. 71-79, 2013.

SÁ, F. V. da S. Ecofisiologia da aceroleira irrigada com água salina sob adubação com fósforo e nitrogênio. 2018. Tese (Doutorado em Engenharia Agrícola) - Universidade Federal de Campina Grande, UFCG, Campina Grande.

SÁ, F. V. da S.; GHEYI, H. R.; LIMA, G. S. de; PAIVA, E. P. de; FERNANDES, P. D.; MOREIRA, R. C. L.; SILVA, L. de A.; FERREIRA NETO, M. Water relations and gas exchanges of West Indian cherry under salt stress and nitrogen and phosphorus doses. Journal of Agricultural Science, Toronto, v. 9, n. 10, p. 168-177, 2017. DOI: 10.5539/jas.v9n10p168
SILVA, E. N. da; RIBEIRO, R. V.; FERREIRA-SILVA, S. L.; VIÉGAS, R. A.; SILVEIRA, J. A. G. Salt stress induced damages on the photosynthesis of physic nut young plants. Scientia Agrícola, Piracicaba, v. 68, n. 1, p. 62-68, 2011. DOI: 10.1590/S0103-90162011000100010

SUASSUNA, J. F.; FERNANDES, P. D.; BRITO, K. S. A. de; NASCIMENTO, R. do; MELO, A. S. de; BRITO, M. E. B. Trocas gasosas e componentes de crescimento em porta-enxertos de citros submetidos à restrição hídrica. Irriga, Botucatu, v. 19, n. 3, p. 464-477, 2014. DOI: 10.15809 irriga.2014v19n3p464

TÁVORA, F. J. A. F.; FERREIRA, R. G.; HERNANDEZ, F. F. F. Crescimento e relações hídricas em plantas de goiabeira submetidas a estresse salino com $\mathrm{NaCl}$. Revista Brasileira Fruticultura, Jaboticabal, v. 23, n. 2, p. 441446, 2001. DOI: 10.1590/S0100-29452001000200050

VOSS, I.; SUNIL, B.; SCHEIBE, R.; RAGHAVENDRA, A. S. Emerging concept for the role of photorespiration as an important part of abiotic stress response. Plant Biology, Stuttgart, v. 15, n. 4, p. 713-722, 2013. DOI: 10.1111/j.1438-8677.2012.00710.x

XU,Z.Z.; ZHOU, G. S. Responses of leaf stomatal density to water status and its relationship with photosynthesis in a grass. Journal of Experimental Botany, Oxford, v. 59, n. 12 , p. $3317-3325,2008$. DOI: $10.1093 /$ jxb/ern 185

ZHOU, S.; DUURSMA, R. A.; MEDLYN, B. E.; KELLY, J. W. G.; PRENTICE, I. C. How should we model plant responses to drought? An analysis of stomatal and nonstomatal responses to water stress. Agricultural and Forest Meteorology, New Haven, v. 182-183, n. 1, p. 204-214, 2013. DOI: 10.1016/j.agrformet.2013.05.009 
